\title{
KEDUDUKAN DAN KEWENANGAN OMBUDSMAN REPUBLIK INDONESIA DALAM MENGAWASI PENYELENGGARAAN PELAYANAN PUBLIK
}

\author{
Muhammad Isa Sya'roni \\ Pondok Pesantren Amanatul Ummah, Siwalankerto Utara 56 Surabaya | \\ isa.syaroni@gmail.com
}

\begin{abstract}
The establishment of the Ombudsman of the Republic of Indonesia was motivated by a powerful demand of society to realize clean and good governance as well as to improve the protection of the rights of the community of the state actor organizers that does not comply with its legal obligations. The Ombudsman has a strong legal foundation because it is based on the norms of law relating to the protection of law for the people and government oversight contained in the constitution. The position of Ombudsman, according to Law No. 37 year 2008 on the Ombudsman of the Republic of Indonesia is a state institution that has the authority to oversee the implementation of public service. It is independent and has no organic relationship with state agencies and other government agencies. In carrying out its duties and authority, it is free from interference of other powers. The establishment of the Ombudsman as a state institution that has the function of supervising the implementation of the bpublic services in Indonesia is appropriate and not contrary to the principles of the Islamic political jurisprudence's supervision, namely the principle of alamr bi al-ma'ruf wa al-nahy 'an al-munkar to realize a peace and public order and to minimize the occurrence of human rights, such as the functions held by the wilayat al-mazalim and wilayat al-hisbah within the Islamic state administration.
\end{abstract}

Keywords: Ombudsman, position, authority, organization, public services

Abstrak: Berdirinya Ombudsman Republik Indonesia dilatarbelakangi oleh adanya tuntutan masyarakat yang amat kuat untuk mewujudkan pemerintahan yang bersih dan penyelenggaraan negara yang baik (clean government dan good governance), serta untuk meningkatkan pemberian perlindungan terhadap hak-hak anggota masyarakat dari 
pelaku penyelenggara negara yang tidak sesuai dengan kewajiban hukumnya. Ombudsman memiliki landasan hukum yang kuat karena dilandasi oleh norma-norma hukum yang berkaitan dengan upaya perlindungan hukum bagi rakyat dan pengawasan terhadap pemerintah yang termuat dalam Undang-undang Dasar. Kedudukan Ombudsman menurut UU RI No. 37 Tahun 2008 Tentang Ombudsman Republik Indonesia adalah sebagai lembaga negara yang mempunyai kewenangan mengawasi penyelenggaraan pelayanan publik, ia bersifat mandiri dan tidak memiliki hubungan organik dengan lembaga negara dan instansi pemerintahan lainnya, serta dalam menjalankan menjalankan tugas dan wewenangnya bebas dari campur tangan kekuasaan lainnya. Dibentuknya Ombudsman sebagai lembaga negara yang mempunyai fungsi mengawasi penyelenggaraan pelayanan publik di Indonesia sesuai dan tidak bertentangan dengan prinsip-prinsip pengawasan dalam fiqh siyasah, yaitu prinsip al-amr bi al-ma'ruf wa alnahy an al-munkar untuk mewujudkan ketentraman dan ketertiban umum dan untuk memperkecil terjadinya hak asasi manusia, seperti fungsi yang dimiliki oleh wilayat al-mazalim dan wilayat al-hisbah dalam ketatanegaraan Islam.

Kata Kunci: Ombudsman, kedudukan, kewenangan, penyelengaraan, dan pelayanan publik

\section{Pendahuluan}

Penyelenggaraan pemerintahan yang bersih dan efektif merupakan dambaan setiap warga negara di manapun. Hal tersebut telah menjadi tuntutan masyarakat yang selama ini hakhak sipil mereka kurang memperoleh perhatian dan pengakuan secara layak, sekalipun hidup di dalam negara hukum Republik Indonesia. Padahal pelayanan kepada masyarakat (pelayanan publik) dan penegakan hukum yang adil merupakan dua aspek yang tidak terpisahkan dari upaya menciptakan pemerintahan demokratis yang bertujuan meningkatkan kesejahteraan masyarakat, keadilan, kepastian hukum dan kedamaian (good governance). ${ }^{1}$

I Sunaryati Hartono, dkk, Panduan Investigasi Untuk Ombudsman Indonesia, Jakarta: Komisi Ombudsman Nasional, 2003), I 
Sebelum reformasi penyelenggaraan negara dan pemerintahan diwarnai dengan praktek maladministrasi, ${ }^{2}$ antara lain terjadinya korupsi, kolusi, nepotisme, sehingga mutlak diperlukan reformasi birokrasi penyelenggaraan negara dan pemerintahan, demi terwujudnya penyelenggaraan negara dan pemerintahan yang efektif dan efesien, jujur, bersih, terbuka, serta bebas dari korupsi, kolusi, dan nepotisme. Penyelenggaraan negara dan pemerintahan yang baik hanya dapat tercapai dengan peningkatan mutu aparatur penyelenggara negara dan pemerintahan, juga penegakan asas-asas pemerintahan umum yang baik. ${ }^{3}$

Setalah reformasi bergulir, reformasi mengamanatkan perubahan kehidupan bernegara, berbangsa, dan bermasyarakat, yaitu kehidupan yang didasarkan pada penyelenggaraan negara dan pemerintahan yang demokratis. Sejalan dengan semangat reformasi itu, pemerintah melakukan perubahan-perubahan mendasar dalam sistem ketatanegaraan dan sistem pemerintahan Republik Indonesia. Perubahan yang dimaksud antara lain dengan membentuk lembaga-lembaga negara dan lembaga-lembaga pemerintahan yang baru. Salah satu diantaranya adalah Komisi Ombudsman Nasional atau juga yang lazim disebut Ombudsman Nasional. ${ }^{4}$ Lembaga ini dibentuk pada tanggal 10 Maret 2000,5

2 Pasal I ayat 3 UU RI No. 37 Tahun 2008 Tentang Ombudsman Republik Indonesia, Maladministrasi adalah perilaku atau perbuatan melawan hukum, melampaui wewenang, menggunakan wewenang untuk tujuan lain dari yang menjadi tujuan wewenang tersebut, termasuk kelalaian atau pengabaian kewajiban hukum dalam penyelenggaraan pelayanan publik yang dilakukan oleh penyelenggara negara dan pemerintahan yang menimbulkan kerugian materiil dan/atau immateriil bagi masyarakat dan orang perseoarangan.

${ }^{3}$ Penjelasan atas UU RI No. 37 Tahun 2008 Tentang Ombudsman Republik Indonesia

${ }^{4}$ Galang Asmara, Ombudsman Nasional dalam Sistem Pemerintahan Negara Republik Indonesia, (Yogyakarta: Laksbang, 2005), 2

${ }^{5}$ Untuk pertama kalinya anggota Komisi Ombudsman Nasional ditetapkan dengan Keputusan Presiden Nomor 44 Tahun 2000, dan berjumlah 8 (delapan) orang termasuk seorang ketua dan seorang wakil ketua yang masing-masing merangkap sebagai anggota. Mereka dilantik dan diambil sumpah pada tanggal 20 Maret 2000 di Istana Negara oleh Presiden Republik Indonesia $\mathrm{KH}$. Abdurrahman Wahid. Adapun susunan keanggotaan Ombudsman Nasional adalah sebagaimana berikut: Ketua merangkap anggota: Antonius Sujata, SH.; Wakil Ketua merangkap anggota Prof. Dr. C. F. G. Sunaryati Hartono, SH.; anggota-anggota: I. Prof. Dr. Bagir Manan, 
berdasarkan Keputusan Presiden No. 44 Tahun 2000 tentang Komisi Ombudsman Nasional.

Pembentukan lembaga Ombudsman bertujuan untuk membantu menciptakan dan mengembangkan kondisi yang kondusif dalam melaksanakan pemberantasan korupsi, kolusi, dan nepotisme $(\mathrm{KKN})$ melalui peran serta masyarakat.

Dalam sistem ketatanegaraan Indonesia, UUD 1945 dengan jelas membedakan cabang-cabang kekuasaan negara dalam bidang legislatif, eksekutif, dan yudikatif yang tercermin dalam fungsifungsi MPR, DPR dan DPD, Presiden dan Wakil Presiden, serta Mahkamah Agung (MA), Badan Pemeriksa Keuangan (BPK), dan Mahkamah Konstitusi (MK) sebagai lembaga-lembaga negara yang utama (mains state organs). ${ }^{6}$

Adapun selain itu, seperti Komisi Yudisial, Kepolisian Negara, Tentara Nasional Indonesia, Bank Sentral, Komisi Pemilihan Umum, Dewan Pertimbangan Presiden, Komisi Nasional Hak Asasi Manusia (KOMNASHAM), Komisi Pengawas Persaiangan Usaha (KPPU), termasuk Ombudsman Republik Indonesia dan sebagainya adalah sebagai lembaga negara bantu (state auxiliary bodies). ${ }^{7}$

Selama ini kita memang telah memiliki lembaga pengawas baik yang bersifat struktural oleh Inspektorat Jenderal, maupun fungsional yaitu Badan Pemeriksa Keuangan. Bahkan terdapat lembaga pengawas yang secara eksplisit dicantumkan dalam Undang-Undang Dasar yaitu Dewan Perwakilan Rakyat, Badan Pemeriksa Keuangan dan ataupun Bank Indonesia. Selain itu, juga ada terdapat organisasi non pemerintah ataupun Lembaga Swadaya Masyarakat yang sekarang ini banyak tumbuh serta turut

SH, MCL; 2. Teten Masduki; 3. Ir. Urip; 4. R.M. Surachman, SH; 5. Pradjoto, SH. MA; 6. KH. Masdar Mas'udi, MA.

${ }^{6}$ Titik Triwulan Tutik, Pokok-Pokok Hukum Tata Negara Indonesia Pasca Amandemen UUD 1945, (Jakarta: Cerdas Pustaka Publisher, 2008), 209

7 lbid, 21 I 
beraktifitas melakukan pengawasan atas pelaksanaan penyelenggaraan negara. ${ }^{8}$

Akan tetapi, kesemua lembaga itu memiliki catatan tersendiri sehingga mengecewakan masyarakat. Lembaga pengawas struktural yang dilakukan oleh Inspektorat Jenderal jelas tidak mandiri karena secara organisatoris merupakan bagian dari kelembagaan atau departemen. Pengawasan fungsional oleh Badan Pemeriksa Keuangan hanya sempit pada masalah pengawasan uang negara dan tidak menerima keluhan yang bersifat individual. Dewan Perwakilan Rakyat dengan fungsi pengawasannya kepada pemerintah lebih bersifat politis karena memang secara kelembagaan adalah lembaga politik dan tidak terlepas dari kelompok yang mereka wakili. Kemudian pengawasan yang dilakukan oleh LSM karena lembaga swasta dan kurang fokus sehingga sering ditanggapi "acuh tak acuh". Oleh karena itu, keberadaan Ombudsman sebagai lembaga negara yang mandiri dan bebas dari kekuasaan manapun serta menerima pengaduan masyarakat sangat dibutuhkan. ${ }^{9}$

Sebelum ada Komisi Ombudsman Nasional pengaduan pelayanan publik hanya disampaikan kepada instansi yang dilaporkan dan penegakannya sering dilakukan oleh pejabat yang dilaporkan sehingga masyarakat belum memperoleh perlindungan yang memadai. Selain itu, untuk menyeleseikan pengaduan pelayanan publik, selama ini dilakukan dengan mengajukan gugatan melalui pengadilan. ${ }^{10}$ Penyelesaian melalui pengadilan tersebut memerlukan waktu cukup lama dan biaya yang tidak sedikit. Untuk itu, diperlukan lembaga tersendiri yakni Ombudsman Republik Indonesia yang dapat menangani pengaduan pelayanan publik dengan mudah dan dengan tidak memungut biaya.

\footnotetext{
${ }^{8}$ Antonius Sujata, dkk., Ombudsman Indonesia: Masa Lalu, Sekarang dan Masa Mendatang, (Jakarta: Komisi Ombudsman Nasional, 2002), 70

${ }^{9}$ lbid, 7l-72

${ }^{10}$ Penjelasan UU RI No. 37 Tahun 2008 Tentang Ombudsman Republik Indonesia.
} 
Setelah berlakunya Undang-Undang Ombudsman Republik Indonesia pada tanggal 7 oktober Tahun 2008, maka Komisi Ombudsman Nasional berubah menjadi Ombudsman Republik Indonesia. Perubahan nama tersebut mengisyaratkan bahwa Ombudsman tidak lagi berbentuk Komisi Negara yang bersifat sementara, tapi merupakan lembaga negara yang permanen sebagaimana lembaga-lembaga negara yang lain, serta dalam menjalankan tugas dan wewenangnya bebas dari campur tangan kekuasaan lainya. ${ }^{11}$

Pengaturan Ombudsman dalam Undang-Undang tidak hanya mengandung konsekuensi posisi politik kelembagaan, namun juga perluasan kewenangan dan cakupan kerja ombudsman yang akan sampai di daerah-daerah. Dalam undang-undang ini dimungkinkan mendirikan kantor perwakilan Ombudsman di daerah Propinsi, Kabupaten/Kota. Dalam hal penanganan laporan juga terdapat perubahan yang fundamental karena Ombudsman diberi kewenangan besar dan memiliki subpoena power (kekuatan memaksa), rekomendasi yang bersifat mengikat, investigasi, serta sanksi pidana bagi yang mengahalang-halangi Ombudsman dalam menangani laporan. ${ }^{12}$

Dalam Undang-undang Republik Indonesia Nomor: 37 Tahun 2008 tentang Ombudsman Republik Indonesia, ditegaskan bahwa yang dimaksud dengan Ombudsman Republik Indonesia adalah lembaga negara yang mempunyai wewenang mengawasi penyelenggaraan pelayanan publik yang diselenggarakan oleh penyelenggara negara dan pemerintahan termasuk yang diselenggarakan oleh Badan Usaha Milik Negara, Badan Usaha Milik Daerah, dan Badan Hukum Milik Negara serta badan swasta atau perseorangan yang diberi tugas menyelenggarakan pelayanan publik tertentu yang sebagian atau seluruh dananya bersumber dari Anggaran Pendapatan dan Belanja Negara dan/atau

"I www.ombudsman.or.id. 20 Juni 2009, Suara Ombudsman Nomor 3 Tahun 2008, Artikel Winarso, Transisi Menuju Ombudsman Republik Indonesia, 3

12 Ibid. 
Anggaran Pendapatan Dan Belanja Daerah. ${ }^{13}$ Tugas Ombudsman adalah memeriksa laporan atas dugaan maladministrasi dalam penyelenggaraan pelayanan publik.

Dengan keberadaan Ombudsman Republik Indonesia ini, penulis ingin meneliti lebih jauh tentang posisi dan kewenanganya dalam mengawasi penyelenggaraan pelayanan publik di Indonesia ditinjau menurut Fiqh Siyasah, yaitu wilayat al-mazalim dan wilayat al-hisbah dalam ketataranegaan Islam, yang mempunyai tugas mengawasi secara langsung pelanggaran hukum dan memiliki wewenang memberikan hukuman bagi pelanggar hukum.

\section{Lembaga Pengawasan dan Pengaduan Masyarakat dalam Ketatanegaraan Islam}

Dalam ketatanegaraan Islam, tujuan pengangkatan penguasa adalah untuk al-amr bi al-ma'ruf wa al-nahy 'an al-munkar, karena kemaslahatan hamba tidak mungkin dicapai kecuali dengan al-amr bi al-ma'ruf wa al-nahy 'an al-munkar. Juga karena kemaslahatan kehidupan dan hamba itu harus dengan taat kepada Allah dan Rasul-Nya. Dan itu hanya dapat dicapai dengan menegakkan alamr bi al-ma'ruf wa al-nahy 'an al-munkar. ${ }^{14}$ Oleh karenanya, dalam Islam ada lembaga yang bertugas al-amr bi al-ma'ruf wa al-nahy 'an al-munkar atau dengan istilah lain melayani pengaduan masyarakat, yang mana masyarakat ini merasa kecewa dengan pelayanan pemerintah dan haknya sebagai warga negara tidak terpenuhi, lembaga ini dikenal dengan sebutan hisbah.

Dalam sistem pemerintahan Islam, kewenangan peradilan (alQada) terbagi kedalam tiga wilayah, yaitu wilayat al-Mazalim, wilayat al-Qada, dan wilayat al-Hisbah. Wilayat al-Mazalim adalah adalah suatu kekuasaan dalam bidang pengadilan yang lebih tinggi dari pada kekuasaan hakim dan kekuasaan Muhtasib. Lembaga ini memeriksa perkara-perkara yang tidak masuk ke

\footnotetext{
${ }^{13}$ Pasal I ayat I UU RI No. 37 Tahun 2008 Tentang Ombudsman Republik Indonesia

${ }^{14}$ Ibnu Taimiyah, Siyasah Syar'iyah, Etika Politik Islam, terjemahan Rofi' Munawwar, (Surabaya: Risalah Gusti, 1999), 71- 72
} 
dalam wewenang hakim biasa. Lembaga ini memeriksa perkaraperkara penganiayaan yang dilakukan oleh penguasa-penguasa dan hakim-hakim ataupun anak-anak dari orang-orang yang berkuasa. ${ }^{15}$

Di antara syarat-syarat yang harus dimiliki seseorang untuk menjadi Qadi al-Mazalim ialah memiliki kedudukan yang tinggi di mata masyarakat, perintahnya dipatuhi, berwibawa, "bersih", tidak ambisius, dan sangat wara' (menjauhi maksiat dan hal-hal yang syubhat), karena dalam menjalankan tugasnya ia membutuhkan gabungan dua sifat sekaligus; ketegasan aparat keamanan dan ketegaran hakim. Dengan kedudukannya yang tinggi, ia berhak mengeluarkan perintah kepada aparat keamanan dan hakim. ${ }^{16}$

Secara umum tugas wilayat al-Mazalim adalah mengajak para pelaku pidana kepada keadilan dengan menakut-nakuti mereka, dan melarang pihak-pihak yang berperkara dari saling memusuhi dengan mengancam mereka. ${ }^{17}$ Lembaga ini memeriksa perkaraperkara yang tidak masuk ke dalam wewenang hakim biasa. Lembaga ini memeriksa perkara-perkara penganiayaan yang dilakukan oleh penguasa-penguasa dan hakim-hakim ataupun anak-anak dari orang-orang yang berkuasa. ${ }^{18}$

Adapun wilayat al-Hisbah adalah suatu tugas keagamaan, masuk ke dalam bidang amar ma'ruf nahi munkar. Tugas ini merupakan tugas fardlu yang harus dilaksanakan oleh penguasa. Oleh karenanya, penguasa harus mengangkat orang-orang yang dipandang cakap untuk tugas ini. ${ }^{19}$

Dasar pendirian lembaga ini adalah firman Allah dalam Surat Ali Imran ayat 104 yang artinya: "Dan hendaklah ada di antara kamu

15 Hasbi Asshiddiqie, Peradilan dan Hukum Acara Islam, (Semarang: Pustaka Rizki Putra, 1997), 92

${ }^{16}$ Imam Al Mawardi, Al-Ahkam As-Sultaniyyah, terjemahan Fadli Bahri, (Jakarta: Darul Falah, 2007), 143

${ }^{17} \mathrm{lbid}$.

${ }^{18}$ Hasbi Asshiddiqie, Peradilan dan Hukum Acara Islam, 92

${ }^{19}$ Topo Santoso, Membumikan Hukum Pidana Islam, (Jakarta: Gema Insani Press, 2003), 57

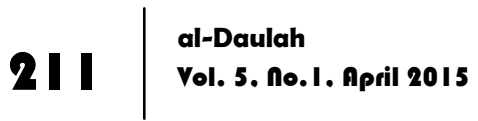


segolongan umat yang menyeru kepada kebajikan, menyuruh kepada yang ma'ruf dan mencegah dari yang munkar; merekalah orang-orang yang beruntung" (Surat Ali Imran: 104). ${ }^{20}$

Menurut al-Mawardi hisbah adalah "memerintah berbuat kebaikan jika jika kebaikan itu ternyata tidak dikerjakan, dan melarang kemunkaran jika ada tanda-tanda bahwa kemunkaran itu dikerjakan". ${ }^{21}$ Oleh karenanya, menurut teori al-Mawardi, hisbah merupakan salah satu bentuk pengawasan bila terjadi pelanggaran terhadap suatu peraturan. Orang yang menjalankan tugas itu disebut Muh\}tasib atau Wali Hisbah atau Nazir fi'l-hisbah. ${ }^{22}$

Al-Mawardi memberikan syarat-syarat yang harus dimiliki muhtasib (petugas hisbah) ialah ia harus orang merdeka, adil, mampu berpendapat, tajam dalam berpikir, kuat agamnya, dan mempunyai pengetahuan tentang kemungkaran-kemungkaran yang terlihat. ${ }^{23}$

Tugas dari hisbah adalah "memberi bantuan kepada orang-orang yang tidak dapat mengembalikan haknya tanpa bantuan dari petugaspetugas hisbah". Tugas hakim adalah: "memutuskan perkara terhadap pertengkaran-pertengkaran yang dikemukakan kepadanya dan mengharuskan orang yang kalah mengembalikan hak-hak orang yang menang". Adapun muhtasib tugasnya ialah: "mengawasi berlakunya tidaknya undang-undang umum dan adab-adab kesusilaan yang tidak boleh dilanggar oleh seorangpun". Dan terkadang muhtasib ini memberikan putusan-putusan dalam hal-hal yang perlu segera diselesaikan. ${ }^{24}$

Menurut al-Mawardi, ada beberapa persamaan dan perbedaan antara hisbah dan mazalim. Persamaan (kemiripan) antara keduanya meliputi dua aspek: pertama, keduanya sama-

20 Depag RI, A/ Qur'an dan Terjemahannya, (Jakarta: Yayasan Penyelenggaraan Penterjemahan Al Qur'an, 2005), 79

${ }^{21}$ Imam Al Mawardi, Al-Ahkam As-Sulthaniyyah, 398

${ }^{22}$ Nur Mufid, Lembaga-Lembaga Politik Islam Dalam Al-Ahka As-Sultaniyyah Karya Al-Mawardi, Qualita Ahsana Vol. I No. 2: Oktober Surabaya, Puslit IAIN Sunan Ampel Surabaya, 1999, 63

${ }^{23}$ Imam Al Mawardi, Al-Ahkam As-Sulthaniyyah, 399

${ }^{24}$ Hasbi Asshiddiqie, Peradilan dan Hukum Acara Islam, 96 - 97 
sama mengandalkan kewibawaan yang diwujudkan melalui kekuatan posisi dan kekerasan cara bertindaknya. Kedua, keduanya sama-sama boleh mengambil tindakan untuk alasan mencapai kemaslahatan masyarakat.

Perbedaannya meliputi dua hal: mazalim dibentuk untuk menangani hal-hal yang tidak dapat diselesaikan oleh qadi, sedangkan hisbah dibentuk untuk meringankan tanggung jawab petugas mazalim. Karena itu, kedudukan mazalim lebih tinggi dari pada hisbah. Petugas mazalim boleh melimpahkan tugasnya kepada Hakim (qadi) dan muhtasib, sementara qadi tidak boleh melimpahkan tugasnya kepada petugas mazalim. Petugas mazalim boleh melimpahkan tugasnya kepada muhtasib, sedangkan muhtasib tidak bisa melimpahkan tugasnya kepada salah satu dari keduanya. Petugas mazalim bisa memberikan hukuman, sementara petugas hisbah tidak boleh memberi hukuman. ${ }^{25}$

\section{Kedudukan Ombudsman Republik Indonesia}

Pengawasan merupakan suatu kegiatan yang ditujukan untuk menjamin agar penyelenggaraan kegiatan sesuai dengan rencana. Dikaitkan dengan hukum pemerintahan, pengawasan dapat diartikan sebagai suatu kegiatan yang ditujukan untuk menjamin sikap tindak pemerintahan/aparat administrasi berjalan sesuai dengan hukum yang berlaku. Jika dikaitkan dengan hukum tata negara, pengawasan berarti suatu kegiatan yang ditujukan untuk menjamin terlaksananya penyelenggaraan negara oleh lembagalembaga kenegaraan sesuai dengan hukum yang berlaku. ${ }^{26}$

Pada dasarnya kewajiban pemerintah/penyelenggara negara kepada masyarakat kaitannya dengan pelayanan publik adalah untuk meningkatkan kualitas dan menjamin penyediaan pelayanan publik sesuai dengaan asas-asas umum pemerintahan

\footnotetext{
${ }^{25}$ Nur Mufid, Lembaga-Lembaga Politik Islam Dalam al-Ahkam as-Sultaniyyah Karya Al-Mawardi, 64

26 Galang Asmara, Ombudsman Nasional dalam Sistem Pemerintahan Negara Republik Indonesia, 125
} 
dan korporasi yang baik serta untuk memberi perlindungan setiap warga negara dan penduduk dari penyalahgunaan wewenang di dalam penyelenggaraan pelayanan publik. ${ }^{27}$ Untuk itu berbagai upaya yang telah dilakukan pemerintah adalah membentuk UU RI No. 37 Tahun 2008 Tentang Ombudsman Republik Indonesia yang disahkan pada tanggal 7 Oktober 2008 dan UU RI No. 25 Tahun 2009 Tentang Pelayanan Publik yang disahkan pada tanggal $18 \mathrm{Juli}$ 2009.

Pengawasan terhadap pelaksanaan penyelenggaraan negara di Indonesia sebelum terbentuknya Ombudsman, telah dilakukan oleh lembaga pengawas baik yang bersifat struktural maupun fungsional. Selain itu juga terdapat organisasi non pemerintah ataupun Lembaga Swadaya Masyarakat yang ikut serta turut beraktifitas melakukan pengawasan atas pelaksanaan penyelenggaraan negara. Berbagai lembaga negara, aparatur pengawas struktural, pengawas fungsional serta organisasi non Pemerintah tersebut memiliki beberapa catatan.

Apabila memperhatikan fungsi Ombudsman sebagaiman tertuang di dalam UU RI No. 37 Tahun 2008 pasal 6 Tentang Ombudsman Republik Indonesia, maka Ombudsman sesungguhnya merupakan salah satu unsur pengawasan dalam sistem pengawasan di Indonesia. Yakni bentuk pengawasan lembaga negara yang bersifat mandiri dan tidak memiliki hubungan organik dengan lembaga negara dan instansi pemerintahan lainnya, serta dalam menjalankan tugas dan wewenangnya bebas dari campur tangan kekuasaan lainnya. ${ }^{28}$

Menurut penulis keberadaan Ombudsman sebagai lembaga pengawas di Indonesia dibandingkan dengan lembaga pengawas yang lain adalah dalam hal independensinya terhadap instansi yang diawasi dan obyek pengawasannya.

Pertama, Lembaga pengawasan struktural yang dilakukan oleh Inspektorat Jenderal yang ada di semua level

\footnotetext{
${ }^{27}$ Konsideran UU RI No. 25 Tahun 2009 Tentang Pelayanan Publik

${ }^{28}$ Pasal 2 UU RI No. 37 Tahun 2008 Tentang Ombudsman Republik Indonesia
} 
lembaga/departemen jelas tidak mandiri karena secara organisatoris merupakan bagian dari lembaga/departemen terkait. Dalam menghadapi dan ataupun menindaklanjuti laporan sangat ditentukan oleh atasan. Pengawasannya bersifat intern artinya kewenangan yang dimiliki dalam melakukan pengawasan hanya mancakup urusan institusi itu sendiri.

Ombudsman tidak demikian, Ombudsman bersifat independen karena Ombudsman bukan bagian dari instansi/lembaga kenegaraan atau pemerintahan manapun yang diawasinya. Sementara fungsi pengawasan yang efektif selalu mempersyaratkan independensi. Tanpa independensi antara pihak yang diawasi dengan yang diawasi kemungkinan besar yang terjadi justru kolusi.

Dalam hal ini dapat kita lihat dalam pasal 2 UU RI No. 37 Tahun 2008 tentang Ombudsman Republik Indonesia yang menyatakan:

"Ombudsman merupakan lembaga negara yang bersifat mandiri dan tidak memiliki hubungan organik dengan lembaga negara dan instansi pemerintahan lainnya serta dalam menjalankan tugas dan wewenangnya bebas dari campur tangan kekuasaan lainnya".

Kedua, badan pengawas fungsional seperti BPK (Badan Pemeriksa Keuangan) dan BPKP (Badan Pengawas Keuangan dan Pembangunan), memang serupa dengan Ombudsman sebagai lembaga independen terhadap instansi yang diawasi. Demikian juga lembaga politik seperti DPR/DPRD, juga independen. Akan tetapi, objek pengawasannya yang membedakan.

Objek pengawasan BPK/BPKP adalah aspek keuangan menyangkut seberapa jauh pembelanjaannya sesuai dengan rencana pembelanjaan dan penganggarannya; dan objek pengawasan DPR/D adalah kebijakan publik yang bersifat umum dan lebih bernuansa politis. Sementara sasaran pengawasan Ombudsman adalah pada "mutu layanan aparat yang bersifat langsung kepada warga masyarakat". Itulah sebabnya, sasaran 
utama kerja Ombudsman adalah keluhan masyarakat terhadap mutu layanan publik dari aparat.

Selain itu, apabila dilihat dari sifat pengawasannya, Ombudsman merupakan lembaga pengawasan yang bersifat preventif. Yakni pengawasan yang ditujukan untuk mencegah terjadinya terjadinya perbuatan atau sikap tindak pemerintah yang melanggar hukum. Dalam hal ini, Antonius Sujata (Ketua Ombudsman) berpendapat bahwa peran Ombudsman dalam upaya pemberantasan KKN berada pada gerbang awal masuk terjadi KKN yaitu mengawasi tindakan maladministrasi oleh aparat/pejabat negara.

Secara lebih spesifik lagi mengenai lembaga yang berhak mengawasi penyelenggaraan pelayanan publik dapat kita lihat dalam UU RI No. 25 Tahun 2009 Tentang Pelayanan Publik yang disahkan pada tanggal 18 Juli 2009, menyatakan bahwa Ombudsman merupakan salah satu lembaga pengawas ekternal selain pengawasan masyarakat dan pengawasan DPR/DPRD yang berhak untuk melakukan pengawasan pelayanan publik. Hal ini termuat dalam pasal 35 ayat 3 UU RI No. 25 Tahun 2009 Tentang Pelayanan Publik: "pengawasan eksternal penyelenggaraan pelayanan publik dilakukan melalui":

a. pengawasan oleh masyarakat berupa laporan atau pengaduan masyarakat dalam penyelenggaraan pelayanan publik;

b. pengawasan oleh ombudsman sesuai dengan peraturan perundang-undangan;

c. pengawasan oleh dewan perwakilan rakyat, dewan perwakilan rakyat daerah propinsi, dewan perwakilan rakyat daerah kabupaten/kota.

Adapun pengawasan internal menurut UU RI No. 25 tahun 2009 dijelaskan dalam pasal 35 ayat 2: "pengawasan internal penyelenggaraan pelayanan publik dilakukan melalui":

a. pengawasan oleh atasan langsung sesuai dengan peraturan perundang-undangan;dan 
b. pengawasan oleh pengawas fungsional sesuai dengan peraturan perundang-undangan.

Mengenai pengawasan internal sudah penulis jelaskan diatas, yaitu pengawasan oleh atasan langsung dan yang dilakukan oleh Inspektorat Jenderal dalam departemen/instansi terkait dan pengawasan oleh pengawas fungsional dilakukan oleh Badan Pengawas Keuangan dan Pembangunan (BPKP).

Menurut penulis, terdapat kesesuaian hukum yang saling menguatkan antara UU RI No. 37 Tahun 2008 tentang Ombudsman Republik Indonesia dengan UU RI No. 25 Tahun 2009 tentang Pelayanan Publik. Yaitu; Ombudsman berdasarkan UU RI No. 37 Tahun 2008 pasal 6 "memiliki fungsi mengawasi penyelenggaraan pelayanan publik", kemudian dalam pasal 35 ayat 3 UU RI No. 245 Tahun 2009 tentang Pelayanan Publik, Ombudsman dinyatakan sebagai salah satu lembaga yang berhak melakukan pengawasan penyelenggaraan pelayanan publik..$^{29}$ Ini artinya, dengan keberadaan UU Pelayanan Publik, Ombudsman akan lebih optimal dalam melaksanakan tugas dan wewenang yang diberikan oleh Undang-undang.

Kaitannya dengan konteks upaya pemberantasan korupsi di Indonesia, Antonius Sujata (ketua Ombudsman) menyatakan bahwa posisi Ombudsman lebih berperan di garda paling depan guna mencegah terjadinya perilaku koruptif setiap aparatur penyelenggara negara/pemerintahan. Pendapat ini dibangun dengan asumsi bahwa sistem pelayanan umum (termasuk proses penegakan hukum) menjadi tidak berjalan dengan baik karena di dalamnya sarat dengan praktek-praktek penyelenggara yang koruptif. ${ }^{30}$ Dengan demikian, posisi Ombudsman adalah sebagai lembaga pengawas yang lebih bersifat preventif.

\footnotetext{
${ }^{29}$ Pasal 35 ayat 3 UU RI No. 25 Tahun 2009 Tentang Pelayanan Publik

${ }^{30}$ Antonius Sujata, Ombudsman dan Gerakan Anti Korupsi, www.ombudsman.go.id. 10 Juni 2008
} 


\section{Kewenangan Ombudsman Republik Indonesia}

Menurut pasal 1 ayat 1 UU RI No. 37 Tahun 2008 Ombudsman adalah lembaga negara yang mempunyai wewenang mengawasi penyelenggaraan pelayanan publik yang diselenggarakan oleh Badan Usaha Milik Negara, Badan Usaha Milik Daerah, dan Badan Hukum Milik Negara serta Badan Swasta atau Perseorangan yang diberi tugas menyelenggarakan pelanan publik tertentu yang sebagian atau seluruh dananya bersumber dari anggaran pendapatan dan belanja negara dan/atau anggaran pendapatan dan belanja daerah. ${ }^{31}$

Dilihat dari tugasnya, Ombudsman berwenang menerima laporan atas dugaan maladministrasi dalam penyelenggaraan pelayanan publik. Dari laporan tersebut, Ombudsman berhak melakukan investigasi terhadap perbuatan aparat yang dilaporkan atau dikeluhkan. Atas dasar hasil investigasi, Ombudsman lalu mengeluarkan rekomendasi.

Menurut UU RI No. 37 Tahun 2008 Tentang Ombudsman Republik Indonesia pasal 8 ayat 1 menyatakan "ombudsman berwenang membuat rekomendasi mengenai penyeleseian laporan, termasuk rekomendasi untuk membayar ganti rugi dan/atau rehabilitasi kepada pihak yang dirugikan". Rekomendasi adalah Kesimpulan, pendapat, dan saran yang disusun berdasarkan hasil investigasi ombudsman, kepada atasan terlapor untuk dilaksanakan dan/atau ditindaklanjuti dalam peningkatan mutu penyelenggaraan administrasi pemerintah yang baik.

Selain itu, menurut UU RI No. 37 Tahun 2008 pasal 8 ayat 2 menerangkan bahwa Ombudsman juga berwenang:

a. menyampaikan saran kepada presiden, kepala daerah, atau pimpinan penyelenggara negara lainnya guna perbaikan dan penyempurnaan organisasi dan/atau prosedur pelayanan publik;

3! UU RI No. 37 Tahun 2008 Tentang Ombudsman Republik Indonesia

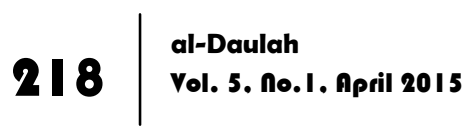


b. menyampaikan saran kepada dewan perwakilan rakyat dan/atau presiden, dewan perwakilan rakyat daerah dan/atau kepala daerah agar terhadap undang-undang dan peraturan perundang-undangan lainnya diadakan perubahan dalam rangka mencegah maladministrasi.

Menurut penulis kewenangan untuk mengawasi penyelenggaraan pelayanan publik seperti yang dimaksud dalam UU RI No. 37 Tahun 2008 pasal 1 ayat 1 dan pasal 8 ayat 1 dan 2 diatas, yang dapat membedakan lembaga pengawas lain di Indonesia baik internal maupun eksternal.

\section{Kedudukan dan Kewenangan Ombudsman dalam Mengawasi} Penyelenggaraan Pelayanan Publik Perspektif Fiqh Siyasah

Menurut kajian fiqh siyasah keberadaan lembaga pengawas sangat penting, hal ini merujuk kepada perintah al-Qur'an yang secara implisit mengamanatkan adanya lembaga pengawasan, yaitu firman Allah SWT dalam surat Ali-Imran ayat 104 yang artinya: "Dan hendaklah ada di antara kamu segolongan umat yang menyeru kepada kebajikan, menyuruh kepada yang ma'ruf dan mencegah dari yang munkar, merekalah orang-orang yang beruntung." 32

Di sini menunjukkan arti pentingnya sebuah lembaga pengawasan, dalam bahasa al-Qur'an "segolongan umat" yang menjalankan fungsi pengawasan yaitu al-amr bi al-ma'ruf wa al-nahy 'an al-munkar, meskipun al-Qur'an tidak menjelaskan lebih lanjut tentang bagaimana bentuk dari lembaga pengawasan tersebut.

Nabi Muhammad SAW juga memerintahkan umatnya untuk menegakkan al-amr bi al-ma'ruf wa al-nahy 'an al-munkar, beliau bersabda dalam Hadis yang diriwayatkan oleh Muslim yang artinya "barang siapa dari kalian yang melihat kemunkaran maka cegahlah dengan tangan (kekuasaan), jika tidak mampu maka cegahlah dengan lisan, jika tidak mampu maka cegahlah dengan hati, dan itu merupakan lemahnya iman".

32 Depag RI, Al Qurán dan Terjemahannya, 79

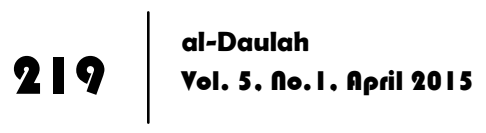


Menurut Ibnu Taimiyah dalam kitab Siyasah Syar'iyahnya menyatakan bahwa Pengangkatan penguasa adalah untuk al-amr bi al-ma'ruf wa al-nahy 'an al-munkar. Karena kemaslahatan hamba tidak mungkin dicapai kecuali dengan al-amr bi al-ma'ruf wa al-nahy 'an al-munkar. Juga karena kemaslahatan kehidupan dan hamba itu harus dengan taat kepada Allah dan Rasul-Nya. Dan itu hanya dapat dicapai dengan menegakkan al-amr bi al-ma'ruf wa al-nahy 'an al-munkar. Oleh karena itu, dalam Islam seorang pemimpin wajib untuk membentuk suatu lembaga yang menangani al-amr bi alma'ruf wa al-nahy 'an al-munkar.

Begitupula menurut pendapat al-Mawardi bahwa imam (khalifah) itu diproyeksikan untuk mengambil alih peran kenabian dalam menjaga agama dan mengatur dunia (al-imamah mawdhuatun li khilafatin nubuwwah fi hirasat al-din wa siyasat aldunya).

Dengan memperhatikan dalil-dalil dan pendapat-pendapat di atas, serta ketentuan dalam UU RI No. 37 Tahun 2008 Tentang Ombudsman Republik Indonesia. Pada dasarnya Ombudsman yang dibentuk di Indonesia tidak bertentangan dengan fiqh siyasah karena secara umum memilki tujuan yang sama, yaitu untuk al-amr bi al-ma'ruf wa al-nahy 'an al-munkar dan untuk kemaslahatan rakyat.

Dalam kajian fiqh siyasah lembaga yang melaksanakan tugas al-amr bi al-ma'ruf wa al-nahy 'an al-munkar dikenal dengan wilayat al-Mazalim dan wilayat al-Hisbah yang menjalankan fungsi pengawasan apabila terjadi penyelewengan pejabat maupun pelanggaran-pelanggaran yang dilakukan oleh rakyat secara umum. Wilayat al-Mazalim dan wilayat al-Hisbah merupakan bagian dari lembaga peradilan Islam.

Secara umum tugas wilayat al-Mazalim adalah mengajak para pelaku pidana kepada keadilan dengan menakut-nakuti mereka, dan melarang pihak-pihak yang berperkara dari saling memusuhi dengan mengancam mereka. Lembaga ini memeriksa perkaraperkara penganiayaan yang dilakukan oleh penguasa-penguasa 
dan hakim-hakim ataupun anak-anak dari orang-orang yang berkuasa.

Menurut al-Mawardi hisbah adalah "memerintah berbuat kebaikan jika kebaikan itu ternyata tidak dikerjakan, dan melarang kemungkaran jika ada tanda-tanda bahwa kemungkaran itu dikerjakan". Karena itu menurut teori al-Mawardi, hlisbah merupakan salah satu bentuk pengawasan bila terjadi pelanggaran terhadap suatu peraturan. Tugas dari wilayat al-Hisbah adalah "memberi bantuan kepada orang-orang yang tidak dapat mengembalikan haknya tanpa bantuan dari petugas-petugas hisbah". Sedangkan muhtasib bertugas mengawasi berlakunya tidaknya undang-undang umum dan adab-adab kesusilaan yang tidak boleh dilanggar oleh seorangpun.

Ombudsman merupakan lembaga negara yang mempunyai fungsi mengawasi penyelenggaraan pelayanan publik yang diselenggarakan oleh penyelenggara negara dan pemerintahan baik di pusat maupun di daerah termasuk yang diselenggarakan oleh Badan Usaha Milik Negara, Badan Usaha Milik Daerah, dan Badan Hukum Milik Negara serta badan swasta atau perseorangan yang diberi tugas menyelenggarakan pelayanan publik tertentu. ${ }^{33}$

Ombudsman berwenang menerima laporan atas dugaan maladministrasi dalam penyelenggaraan pelayanan publik. Dari laporan tersebut, Ombudsman berhak melakukan investigasi terhadap perbuatan aparat yang dilaporkan atau dikeluhkan. Atas dasar hasil investigasi, Ombudsman lalu mengeluarkan Rekomendasi.

Ombudsman juga berwenang melakukan investigasi atas prakarsa sendiri terhadap dugaan maladminstrasi dalam penyelenggaraan pelayanan publik. Jadi tanpa didahului oleh adanya suatu laporan/pengaduan atau keluhan masyarakat (pasal 7 huruf d UU RI No. 37 Tahun 2008 Tentang Ombudsman Republik Indonesia).

${ }^{33}$ Pasal 6 UU RI No. 37 Tahun 2008 Tentang Ombudsman Republik Indonesia

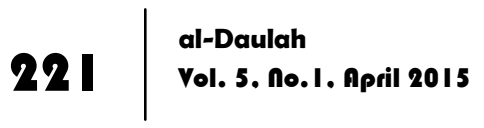


Dengan demikian, menurut penulis apabila melihat posisi dan kewenangan yang dijalankan oleh Ombudsman sarat dengan pengawasan yang dijalankan oleh wilayat al-mazalim dan wilayat alhisbah dalam ketatanegaraan Islam. Dengan kata lain Ombudsman mengambil prinsip-prinsip lembaga pengawasan dalam Islam.

Secara posisi kelembagaan, Ombudsman sebagai lembaga pengawasan negara yang independen, memiliki kesamaan dengan wilayat al-hisbah dan wilayat al-mazalim yaitu sebagai lembaga peradilan Islam yang juga independen dari kekuasaan Khalifah. Hanya bedanya Ombudsman sebagai lembaga negara yang mandiri di Indonesia sedangkan wilayat al-hisbah dan wilayat almazalim berada dalam lembaga peradilan Islam.

Secara kewenangan dan mekanisme kerjanya, Ombudsman juga memiliki kesamaan dengan wilayat al-hisbah. Yaitu Ombudsman berwenang menerima laporan atas dugaan maladministrasi dalam penyelenggaraan pelayanan publik, kemudian melakukan investigasi terhadap perbuatan aparat yang dilaporkan atau dikeluhkan, dan selanjutnya mengeluarkan rekomendasi. wilayat al-hisbah juga demikian, dimana muhtasib menerima pengaduan dari masyarakat atas pelanggaran terhadap suatu peraturan kemudian memberikan sanksi ta'zir (sanksi disiplin). Keduanya juga mempunyai tugas dan wewenang yang sama untuk berinisiatif sendiri melakukan pengawasan atas suatu perbuatan maladministrasi atau pelanggaran terhadap peraturan yang berada dalam kompetensinya.

Singkatnya, menurut penulis bahwa dibentuknya Ombudsman di Indonesia sesuai dan tidak bertentangan dengan prinsip-prinsip pengawasan dalam fiqh siyasah. Yaitu prinsip alamr bi al-ma'ruf wa al-nahy 'an al-munkar untuk mewujudkan ketentraman dan ketertiban umun dan untuk memperkecil terjadinya hak asasi manusia seperti yang fungsi yang dimiliki oleh wilayat al-mazalim dan wilayat al-hisbah dalam ketatanegaraan Islam. 


\section{Penutup}

Berdirinya Ombudsman Republik Indonesia dilatarbelakangi oleh adanya tuntutan masyarakat yang amat kuat untuk mewujudkan pemerintahan yang bersih dan penyelenggaraan negara yang baik (clean government dan good governance), serta untuk meningkatkan pemberian perlindungan terhadap hak-hak anggota masyarakat dari pelaku penyelenggara negara yang tidak sesuai dengan kewajiban hukumnya. Keberadaan Ombudsman Republik Indonesia memiliki landasan yuridis yang kuat karena dilandasi oleh norma-norma hukum yang berkaitan dengan upaya perlindungan hukum bagi rakyat dan pengawasan terhadap pemerintah yang termuat dalam Undang-undang Dasar.

Kedudukan Ombudsman menurut UU RI No. 37 Tahun 2008 Tentang Ombudsman Republik Indonesia adalah sebagai lembaga negara yang mempunyai kewenangan mengawasi penyelenggaraan pelayanan publik, ia bersifat mandiri dan tidak memiliki hubungan organik dengan lembaga negara dan instansi pemerintahan lainnya, serta dalam menjalankan menjalankan tugas dan wewenangnya bebas dari campur tangan kekuasaan lainnya.

Dibentuknya Ombudsman sebagai lembaga negara yang mempunyai fungsi mengawasi penyelenggaraan pelayanan publik di Indonesia sesuai dan tidak bertentangan dengan prinsip-prinsip pengawasan dalam fiqh siyasah. Yaitu prinsip al-amr bi al-ma'ruf wa al-nahy 'an al-munkar untuk mewujudkan ketentraman dan ketertiban umun dan untuk memperkecil terjadinya hak asasi manusia, seperti fungsi yang dimiliki oleh wilayat al-Mazalim dan wilayat al-Hisbah dalam ketatanegaraan Islam.

\section{Daftar Pustaka}

Asmara, Galang. Ombudsman Nasional Dalam Sistem Pemerintahan Negara Republik Indonesia. Yogyakarta: Laksbang, 2005 
Asshiddiqie, Hasbi. Peradilan dan Hukum Acara Islam. Semarang: Pustaka Rizki Putra, 1997

Departemen Agama RI. Al Qur'an dan Terjemahannya. Jakarta:

Yayasan Penyelenggaraan Penterjemahan Al Qur'an, 2005

Hartono, Sunaryati, dkk. Panduan Investigasi Untuk Ombudsman

Indonesia. Jakarta: Komisi Ombudsman Nasional, 2003

Mawardi (al-), Imam. Al-Ahkam As-Sulthaniyyah. terjemahan Fadli Bahri. Jakarta: Darul Falah, 2007

Mufid, Nur. Lembaga-Lembaga Politik Islam Dalam Al-Ahka AsSultaniyyah Karya Al-Mawardi. Qualita Ahsana Vol. 1 No. 2: Oktober Surabaya, Puslit IAIN Sunan Ampel Surabaya, 1999

Santoso, Topo. Membumikan Hukum Pidana Islam. Jakarta: Gema Insani Press, 2003

Sujata, Antonius, dkk. Ombudsman Indonesia: Masa Lalu, Sekarang Dan Masa Mendatang. Jakarta: Komisi Ombudsman Nasional, 2002

Taimiyah, Ibnu. Siyasah Syar'iyah. terjemahan Rofi' Munawwar. Surabaya: Risalah Gusti, 1999

Tutik, Titik Triwulan. Pokok-Pokok Hukum Tata Negara Indonesia Pasca Amandemen UUD 1945. Jakarta: Cerdas Pustaka Publisher, 2008

Kepres No. 44 Tahun 2000 Tentang Komisi Ombudsman Nasional Ketetapan MPR No: VIII/MPR/2001 Tentang Rekomendasi Arah

Kebijakan Negara Yang Bersih dan Bebas Dari Korupsi Kolusi dan Nepotisme

UU RI No. 37 Tahun 2008 Tentang Ombudsman Republik Indonesia, Bandung, Fokusmedia

UU RI No. 25 Tahun 2009 Tentang Pelayanan Publik

\section{Website}

www.ombudsman.or.id diakses tanggal 20 Juni 2009

Suara Ombudsman Nomor 3 Tahun 2008, Jakarta, Komisi Ombudsman Naional 